\title{
Introducing the montado, the cork and holm oak agroforestry system of Southern Portugal
}

\author{
T. Pinto-Correia $\cdot$ N. Ribeiro $\cdot$ P. Sá-Sousa
}

Received: 7 December 2010/Accepted: 26 March 2011/Published online: 19 April 2011

(C) Springer Science+Business Media B.V. 2011

\begin{abstract}
The Portuguese montado is an agro-silvo pastoral system quite similar to the dehesa in Spain, and covering in Portugal most of the Southern region of the country, Alentejo. The trees in the montado are cork oh holm oak, and the system is mostly acknowledged due to the cork production, but also due to its singular savanna like land cover pattern, its multiple and complementary productions, the support of a diversity of ecosystems services and its biodiversity. The present special issue covers the diversity of components of the montado and of perspectives required to understand and assess the functioning of the system. This Editorial introduces the montado system, describes its extension and similarities to the dehesa in Spain, and addresses the multiple productions and externalities of the montado. It also refers to the several components of the system. It focus on the uniqueness and values of this system, stressing its potential and threats, and the requirements for integrated knowledge production. In the end of the Editorial, each one of the papers that compose the special issue are presented.
\end{abstract}

Keywords Agro-silvo pastoral system · Agroforestry $\cdot$ Montado $\cdot$ Dehesa $\cdot$ Multifunctionality

T. Pinto-Correia $(\bowtie) \cdot$ N. Ribeiro · P. Sá-Sousa

University of Évora, Evora, Portugal

e-mail: mtpc@uevora.pt

\section{The montado}

The Portuguese montado, evergreen oak parklands consisting of a multifunctional silvo-pastoral system that covers about 800,000 ha in Portugal, mainly in the region of Alentejo, where it covers 730,000 ha (Costa et al. 2009). A similar system can also be found in South-East Spain, the dehesa, mostly in Extremadura (1.25 M ha) and Andalucia (700,000 ha). Thus, according to Olea and San Miguel-Ayanz (2006), the montado/dehesa agroforestry systems may cover an area of about 3.5-4.0 $\mathrm{M}$ ha in the southwestern Iberian Peninsula, and is for the most part, still under production today. The area covered by this land use system is thus of large relevance in the Southern European context.

The international acknowledgement of this system stems originally from cork production, with Portugal contributing about $33 \%$ of the world cork oak area, and $54 \%$ of the mean annual world cork production (Ribeiro et al. 2010). Most important today, in international terms, the montado is also acknowledged due to its specificity and value as a particular landscape, its biodiversity support, aesthetic and identity values, attractiveness for recreation and environmental balance (Berrahmouni and Regato 2007; Costa et al. 2009; Surová and Pinto-Correia 2008; Surová et al. 2011). The montado is considered a High Nature Value Farming System, according to the European classification proposed by the European Environmental Agency (Paracchini et al. 2008), 